\title{
PERSEPSI MASYARAKAT TERHADAP \\ KEBERADAAN INDUSTRI TEPUNG IKAN DITINJAU DARI TINGKAT \\ KEBAUAN, BAU DAN AIR LIMBAH \\ (Studi Kasus di Desa Purworejo Kecamatan Pati)
}

\author{
PUBLIC PERCEPTIONS ON THE EXISTENCE \\ OF FISH MEAL INDUSTRY BASED ON \\ LEVEL OF ODOR, ODOR AND WASTEWATER \\ (Case Study in Purworejo Village, Pati Regency)
}

\author{
Arieyanti Dwi Astuti \\ Kantor Penelitian dan Pengembangan Kabupaten Pati \\ E-mail: ariey_antik@yahoo.com
}

Naskah Masuk: 22 September 2015 Naskah Revisi: 1 Oktober 2015 Naskah Diterima: 13 Oktober 2015

\begin{abstract}
Industry and people who live around the industry area are two component that affect each other. The indutrial activities have impacts for the surrounding communities, positive and negative effects. This research aims to describe the public perception about level of odor, odor and wastewater. Location of the research in Purworejo Village, Pati Subdistrict. Research method is descriptive with quantitative qualitative approach. Data source of primary data obtained from questionnaires and interviews. The results of the research show that the public perception for : a) Sub variable level of odor included in the category "Sangat Menyengat" with score 123;2) Sub variable odor included in the category "Sangat Terganggu" with score 115; 3) Sub variable wastewater included in the category "Sangat Terganggu" with score 111.
\end{abstract}

Keywords: wastewater, odor, fish meal industry, publi perception, level of odor

\begin{abstract}
ABSTRAK
Industri dan masyarakat yang bermukim disekitarnya merupakan dua komponen yang saling mempengaruhi. Aktivitas industri tersebut memberi dampak bagi masyarakat sekitarnya, baik dampak positif dan negatif. Penelitian ini bertujuan untuk mengetahui persepsi masyarakat terhadap keberadaan industri pembuatan tepung ikan ditinjau dari tingkat kebauan, bau/aroma serta air limbah yang ditimbulkan. Lokasi penelitian berada di Desa Purworejo Kabupaten Pati. Metode penelitian adalah deskriptif dengan pendekatan kuantitatif kualitatif. Sumber data berupa data primer dari pengamatan kuesioner dan wawancara. Hasil penelitian yaitu persepsi masyarakat untuk ; 1) Sub variabel tingkat kebauan masuk dalam kategori sangat menyengat dengan total nilai skor 123; 2) Sub variabel bau/aroma masuk dalam kategori sangat terganggu dengan nilai skor 115; 3) Sub variabel air limbah adalah termasuk dalam kategori Tidak Terganggu dengan total nilai skor 111.
\end{abstract}

Kata kunci: air limbah, bau, industri tepung ikan, persepsi masyarakat, tingkat kebauan 


\section{PENDAHULUAN}

Salah satu industri pengolahan hasil perikanan yang terdapat di jalan Pati-Juwana, tepatnya di Desa Purworejo Kecamatan Pati adalah industri pembuatan tepung ikan. Tepung ikan mengandung protein hewani yang cukup tinggi, itulah mengapa tepung ikan banyak digunakan sebagai bahan baku pembuatan pakan ternak dan sebagai pakan ikan. Bila dilihat dari sisi kualitasnya, sampai saat ini masih sulit mencari pengganti tepung ikan. Permintaan tepung ikan melebihi dari produksi tepung ikan yang mampu dihasilkan oleh industri lokal sehingga kebutuhan tepung ikan dalam negeri pada akhirnya dipenuhi dari impor. Oleh karena itu, industri tepung ikan mempunyai prospek yang menjanjikan untuk dikembangkan karena tingginya permintaan akan tepung ikan. Industri pembuatan tepung ikan di Desa Purworejo Kecamatan Pati mampu mengolah $\pm 100-200$ ton ikan per hari untuk menghasilkan tepung ikan sebanyak 25 - 50 ton/hari.

Industri dan masyarakat yang bermukim disekitarnya merupakan dua komponen yang saling mempengaruhi. Aktivitas industri tersebut tidak dapat dihindari memiliki dampak bagi masyarakat sekitarnya, baik dampak positif (seperti penciptaan lapangan pekerjaan dan peningkatan taraf ekonomi) maupun dampak negatif (seperti penurunan kualitas lingkungan dan kesehatan masyarakat). Masyarakat memiliki cara pandang sendiri terhadap industri tersebut yang dapat diartikan sebagai persepsi. Persepsi masyarakat tersebut bisa berbeda antara satu individu dengan individu lainnya.

Berdasarkan uraian latar belakang diatas, maka penelitian ini bertujuan untuk mengetahui persepsi masyarakat terhadap keberadaan industri pembuatan tepung ikan ditinjau dari tingkat kebauan, bau/aroma serta air limbah yang ditimbulkan.

\section{TINJAUAN PUSTAKA}

\section{Proses Pembuatan Tepung Ikan}

Pada umumnya, proses pembuatan tepung ikan hanyalah meliputi pembersihan bahan baku berupa ikan yang kemudian dilanjutkan dengan proses perebusan, pengepresan, pengeringan, penggilingan, pengayakan dan pengemasan. Semua proses tersebut sudah dilakukan menggunakan mesin. Pada saat ikan datang, ikan akan mengeluarkan bau (limbah gas) berupa bau busuk. Hal ini sesuai dengan laporan yang ditulis Laili (2010), yang menyatakan bahwa limbah gas dari pabrik tepung ikan berasal dari bau ikan rucah, motor diesel dan asap kendaraan yang keluar masuk pabrik.

Proses perebusan ikan bertujuan untuk mengkoagulasi (menggumpalkan) protein dan mempermudah pemisahan air dan minyak. Cooker yang banyak dipakai untuk merebus ikan berupa silinder panjang horizontal yang dipanaskan dengan uap air di dalam system jacket nya. Beberapa jenis cooker diberi pelengkapan untuk menginjeksikan uap air ke dalam ruang perebusan (Laili, 2010). Pada proses ini dihasilkan gas (uap) yang selama ini diduga sebagai sumber bau.

Setelah bahan baku ikan datang, ikan akan dicuci, kemudian diolah dengan memasukkannya ke dalam mesin untuk mengalami proses-proses tersebut. Meski prosesnya sederhana, namun membutuhkan keterampilan dan pengalaman khusus untuk menghasilkan 
produk tepung ikan yang bermutu tinggi (Widyasari dkk., 2013).

\section{Bau (Odor)}

Keputusan Menteri Negara Lingkungan Hidup No. 50 Tahun 1996 menyatakan bahwa bau adalah suatu rancangan dari zat yang diterima oleh indera penciuman. Kebauan adalah bau yang tidak diinginkan dalam kadar dan waktu tertentu yang dapat mengganggu kesehatan manusia dan kenyamanan lingkungan. Bau ini berasal dari sumber bau atau zat odoran, yang didefinisikan sebagai setiap zat yang dapat menimbulkan rangsangan bau pada keadaan tertentu.

Bau busuk yang menyengat pada industri pembuatan tepung ikan diduga dihasilkan dari proses pembongkaran muatan bahan baku (ikan) dan proses perebusan ikan. Bau busuk ini memiliki karakter yang khas yaitu bau amis. Sebagaimana diketahui bahwa ikan yang digunakan pada proses ini adalah ikan yang kondisinya sudah tidak segar (agak busuk). Ikan sendiri merupakan salah satu bahan pangan yang sangat mudah membusuk. Hal ini dikarenakan tingginya kandungan air, protein dan asam lemak tak jenuh yang terdapat pada ikan (Nugraheni, 2010).

\section{Air Limbah}

Output lain dari proses produksi selain produk akhir adalah limbah, baik itu limbah cair, limbah padat maupun limbah gas. Limbah cair atau air limbah yang dalam penelitian ini berasal dari industri tepung ikan merupakan air limbah yang memiliki kandungan dominan adalah lemak. Lemak merupakan salah satu unsur pencemar yang apabila terdegradasi oleh mikroorganisme akan menimbulkan bau busuk dan menyebabkan air menjadi coklat kehitaman.

\section{Persepsi Masyarakat}

Persepsi dapat didefinisikan sebagai suatu proses dimana seseorang menyeleksi, mengorganisasikan dan menginterpretasikan stimulus keadaan (Simamora dalam Anwar, 2012). Sehingga dapat disimpulkan bahwa persepsi masyarakat adalah sebuah proses dimana sekelompok individu yang hidup dan tinggal bersama dalam wilayah tertentu, memberikan tanggapan terhadap hal-hal yang dianggap menarik dari lingkungan tempat tinggal mereka.

\section{METODE PENELITIAN}

Penelitian ini dilakukan di Desa Purworejo Kecamatan Pati, Kabupaten Pati. Dimana lokasi ini diambil karena berdekatan dengan industri tepung ikan. Pelaksanaan penelitian ini berlangsung pada bulan Juni - September 2015.

Jenis penelitian ini adalah deskriptif dengan pendekatan kuantitatif kualitatif. Populasi pada penelitian ini adalah warga masyarakat Desa Purworejo (1170 KK) (Data Monografi Desa, 2015). Penentuan sampel menggunakan Rumus Slovin dan perhitungan tersebut menghasilkan sampel sebanyak 43 responden yang akan diambil dari masing-masing dukuh (4 dukuh). Adapun instrumen pada penelitian ini disajikan pada Tabel 1. 
Tabel 1.

Variabel dan Indikator Pengukuran

\begin{tabular}{cll}
\hline Variabel & \multicolumn{1}{c}{ Sub Variabel } & \multicolumn{1}{c}{ Indikator } \\
\hline Persepsi Masyarakat & a. Tingkat kebauan & 1. Bau menyengat \\
& b. Bau/aroma & 1. Bau busuk \\
& c. Air limbah & 1. Air berbau \\
& & 2. Saluran sungai \\
\hline
\end{tabular}

Sumber: Hasil Pengamatan, 2015.

\section{HASIL DAN PEMBAHASAN}

\section{Persepsi Masyarakat Terhadap Tingkat Kebauan}

Untuk melihat persepsi masyarakat di Desa Purworejo terhadap keberadaan industri tepung ikan ditinjau dari sub variabel bau dapat dilihat pada Tabel 2.

Tabel 2 menunjukkan hasil kuesioner dan wawancara dengan responden di Desa Purworejo Kecamatan Pati, dimana hasil total skor nya adalah 123 dengan persentase kategori tertinggi adalah Sangat Menyengat sebesar $88,37 \%$. Hal ini berarti bahwa sebagian besar responden memberikan jawaban sangat menyengat saat diajukan pertanyaan mengenai persepsi bau busuk yang sering tercium di sekitar tempat tinggal mereka.

Seluruh masyarakat Desa Purworejo yang menjadi responden pada penelitian ini berpersepsi bahwa bau sangat menyengat tersebut bersumber dari 2 (dua) industri tepung ikan yang berada tidak jauh dari tempat mereka tinggal. Persepsi para responden ini didasarkan pada pengalaman mereka selama tinggal disana tidak pernah tercium bau seperti ini sebelum industri tepung ikan tersebut beroperasi, meskipun saat itu pabrik pembekuan ikan (cold storage) yang berada di depan industri tepung ikan sudah beroperasi sebelumnya. Sebanyak 18,6\% responden menyatakan bahwa bau sangat menyengat tersebut muncul sejak Industri Tepung Ikan A beroperasi (hasil wawancara dengan S9, S23, S26, S28, S31, S36, S41 dan S42). Mereka menyayangkan keputusan Pemerintah Desa Purworejo yang justru malah kembali memberikan ijin pada pabrik baru dengan produk yang sama (pabrik tepung ikan) yaitu Industri Tepung Ikan B. Sedangkan $4,65 \%$ dari responden menyatakan bahwa Industri Tepung Ikan B lah yang mengeluarkan bau sangat menyengat tersebut (S19 dan S25). Salah satu responden tersebut (S25) merupakan karyawan Industri Tepung Ikan A sehingga dia menyatakan bahwa bukan pabrik tempat bekerjanya yang menjadi sumber bau sangat menyengat tersebut. Sisanya $76,75 \%$ dari responden menyatakan bahwa bau sangat menyengat tersebut berasal dari dua industri tepung ikan, baik Industri A maupun Industri B. 
Tabel 2.

Distribusi Frekuensi Responden Mengenai Persepsi Masyarakat Sub Variabel Tingkat Kebauan

\begin{tabular}{|c|c|c|c|c|c|c|}
\hline No & Indikator & Kategori Jawaban & $\begin{array}{l}\text { Nilai } \\
\text { Skor }\end{array}$ & $\begin{array}{c}\text { Frekuensi } \\
\text { (orang) }\end{array}$ & Jumlah & $\begin{array}{c}\text { Persentase } \\
(\%)\end{array}$ \\
\hline \multirow[t]{4}{*}{1} & \multirow{3}{*}{$\begin{array}{l}\text { Bau } \\
\text { menyengat }\end{array}$} & Sangat Menyengat & 3 & 38 & 114 & 88,37 \\
\hline & & Menyengat & 2 & 4 & 8 & 9,30 \\
\hline & & Tidak Menyengat & 1 & 1 & 1 & 2,33 \\
\hline & \multicolumn{2}{|c|}{ Jumlah } & & 43 & 123 & 100 \\
\hline
\end{tabular}

Sumber: Pengolahan Data (2015).

Diantara ketiga kategori pada indikator bau menyengat, diperoleh nilai skor yang sangat tinggi yaitu pada kategori Sangat Menyengat. Meskipun demikian beberapa responden ada yang menjawab Menyengat yaitu sebanyak 9,30\%. Hal ini diduga karena lokasi tempat tinggal responden yang berada cukup jauh dari sumber bau (S22, S25, S32 dan S40). Sedangkan sisanya 2,33\% menyatakan bahwa bau tersebut Tidak Menyengat. Gambaran yang lebih jelas mengenai persepsi masyarakat terhadap keberadaan industri tepung ikan ditinjau dari tingkat kebauan disajikan pada Tabel 3.

Tabel 3.

Skala Persepsi Masyarakat Untuk Sub Variabel Tingkat Kebauan

\begin{tabular}{cc}
\hline Kategori & Nilai Skor \\
\hline Sangat Menyengat & $\mathbf{1 0 0 , 4 - 1 2 9}$ \\
Menyengat & $71,7-100,3$ \\
Tidak Menyengat & $43-71,6$ \\
\hline Sumber: Pengolahan Data (2015).
\end{tabular}

Persepsi masyarakat terhadap keberadaan industri tepung ikan mempunyai total skor 123 seperti yang dijelaskan pada Tabel 2. Nilai skor ini masuk dalam kategori Sangat Menyengat dengan range skor (100,4129) menurut skala persepsi masyarakat untuk sub variabel tingkat kebauan pada Tabel 3. Total skor ini menandakan bahwa sebagian masyarakat merasakan bau yang sangat menyengat akibat proses produksi dari industri tepung ikan.

Sebanyak 31 orang responden $(72,09 \%)$ mengatakan bahwa bau tersebut muncul karena bahan baku digunakan berupa ikan yang kondisinya tidak bagus (sudah mulai membusuk). Responden lainnya sebanyak 6,98\% memberikan jawaban bahwa bau busuk tersebut dikarenakan asap yang keluar dari cerobong saat proses produksi berlangsung. Sedangkan sebesar $4,65 \%$ menjawab bahwa bau busuk tersebut disebabkan pengolahan limbah yang kurang baik. Sisanya sebanyak 16,28\% menjawab tidak tahu.

Asap yang keluar dari cerobong pabrik merupakan salah satu jawaban yang diberikan responden sebagai sumber bau dengan persentase 6,98\%. Hal ini didasarkan pada fakta bahwa tiap kali ada asap yang keluar dari cerobong 
maka bau busuk menyengat akan segera tercium. Keluarnya asap ini menandakan bahwa industri tersebut sedang berproduksi, jadi memang sangat dimungkinkan jika warga mencium bau busuk menyengat sesaat setelah asap keluar dari cerobong. Sebenarnya, asap tersebut merupakan hasil pembakaran batubara yang menjadi bahan energi dalam proses produksi di industri tersebut. Oleh warga, keluarnya asap tersebut menjadi pertanda bahwa bau busuk menyengat akan mulai tercium setelahnya.

Dari jawaban responden tersebut menggambarkan bahwa persepsi sebagian besar masyarakat terhadap penyebab sumber bau dari industri tepung ikan tersebut adalah karena bahan baku yang digunakan berupa ikan busuk sehingga ketika diolah akan mengeluarkan bau busuk yang sangat menyengat. Dari hasil kuesioner dan wawancara ini secara tidak langsung dapat dinyatakan bahwa keberadaan 2 (dua) industri tepung ikan di desa tersebut berpotensi menyebabkan pencemaran lingkungan yang dalam hal ini adalah pencemaran udara.

\section{Persepsi Masyarakat Terhadap Bau/Aroma}

Adapun untuk jawaban responden mengenai persepsi masyarakat terhadap sub variabel bau/aroma pada penelitian ini disajikan pada Tabel 4.

Tabel 4.

Distribusi Frekuensi Responden Mengenai Persepsi Masyarakat Sub Variabel Bau

\begin{tabular}{|c|c|c|c|c|c|c|}
\hline No & Indikator & Kategori Jawaban & Nilai Skor & $\begin{array}{c}\text { Frekuensi } \\
\text { (orang) }\end{array}$ & Jumlah & $\begin{array}{c}\text { Persentase } \\
(\%)\end{array}$ \\
\hline \multirow[t]{4}{*}{2} & Bau busuk & Sangat Terganggu & 3 & 30 & 90 & 69,77 \\
\hline & & Terganggu & 2 & 12 & 24 & 27,91 \\
\hline & & Tidak Terganggu & 1 & 1 & 1 & 2,33 \\
\hline & & mlah & & 43 & 115 & 100 \\
\hline
\end{tabular}

Sumber: Pengolahan Data (2015).

Tabel 4 menunjukkan bahwa persentase terbesar sebanyak $69,77 \%$ adalah kategori Sangat Terganggu. Hal menunjukkan bahwa sebagian besar masyarakat merasa sangat terganggu dengan adanya bau yang ditimbulkan dari proses produksi industri tepung ikan yang berada di sekitar permukiman responden. Bau busuk tersebut sudah sangat mengganggu masyarakat sekitarnya kurang lebih sejak tahun 2012.

Waktu munculnya bau tersebut tidak bisa dipastikan (sewaktu-waktu), karena meskipun industri beroperasi setiap hari pada waktu yang sama, bau hanya akan tercium jika angin berhembus dari arah yang berlawanan menuju ke permukiman warga. Kedua industri tepung ikan tersebut terletak bersebelahan.

Sedangkan lokasi tiap dukuh di Desa Purworejo berbeda-beda jika dilihat berdasarkan arah mata angin dari industri tepung ikan. Arah dan perkiraan jarak pada masing-masing dukuh di Desa Purworejo disajikan pada Tabel 5. 
Tabel 5.

Arah dan Perkiraan Jarak Dukuh di Desa Purworejo dari Industri Tepung Ikan

\begin{tabular}{ccc}
\hline Dukuh & Arah & Perkiraan Jarak $(\mathrm{km})$ \\
\hline Pondowan & Barat & 1,02 \\
Kelingan & Utara/Barat & 1,48 \\
Jetak & Barat & 2,22 \\
Guyangan & Timur & 0,54 \\
\hline
\end{tabular}

Sumber: Hasil Pengamatan, 2015.

Menurut hasil kuesioner dan wawancara dengan responden S23, S33, S34 dan S36, proses produksi tepung ikan berlangsung 24 jam untuk Industri Tepung Ikan A karena ada beberapa karyawan Industri Tepung Ikan A yang masuk kerja pada shift $3(23.00-07.00)$ yang tinggal di sekitar mereka, sedangkan untuk Industri Tepung Ikan B berlangsung sesuai jam kerja, bahkan beberapa hari tidak berproduksi (pasokan ikan tidak selalu ada). Itulah alasannya kenapa bau busuk menyengat bisa muncul sewaktu-waktu bahkan ketika jam tidur malam.

Untuk sebagian besar dukuh di Desa Purworejo, yaitu Dukuh Pondowan, Dukuh Kelingan dan Dukuh Jetak, bau busuk akan tercium bila angin berhembus dari timur ke barat/utara, karena lokasi dukuh tersebut berada di barat dan utara pabrik. Sedangkan untuk Dukuh Guyangan, karena lokasinya yang berada di timur pabrik maka bau busuk akan tercium dan sangat mengganggu ketika angin berhembus dari barat ke timur. Bau busuk akan semakin kuat tercium saat kondisi udara lembab (mendung, hujan, tidak ada panas).

Bahan baku yang digunakan pada industri tepung ikan ini merupakan ikan yang kondisinya sudah tidak segar lagi (agak busuk). Bahan baku ini ketika diproses dengan pemanasan dan pengeringan, akan menghasilkan uap panas. Uap panas inilah yang oleh sebagian masyarakat Desa Purworejo, dianggap sebagai sumber bau.
Masyarakat sangat terganggu dengan keberadaan bau busuk yang sangat menyengat ini, bahkan beberapa responden merasakan mual (muntah) dan pusing dengan frekuensi sering atau kadang-kadang. Dan sekarang, warga sudah mulai terbiasa dengan bau tersebut. Namun warga tetap menginginkan supaya pihak pabrik menghilangkan atau paling tidak mengurangi bau busuk yang ditimbulkan dari proses pembuatan tepung ikan tersebut.

Dampak negatif dari bau busuk ini, salah satunya adalah penurunan status sosial ekonomi daerah tersebut. Hal ini diperkuat dengan penuturan S1 bahwa daerah tersebut dikenal karena bau busuk yang menyengat. Dampak lain dari bau busuk ini adalah meningkatnya jumlah tikus yang menyerang sawah warga. Beberapa warga mengeluhkan gagal panen sejak pabrik tepung ikan tersebut berdiri di Desa Purworejo. Bahkan menurut S7, lahan sawah milik beliau seluas 2 ha yang berada di timur pabrik tepung ikan gagal panen akibat hama tikus, padahal sebelumnya tidak pernah terjadi kasus semacam ini. Mereka menyakini bahwa merajalelanya hama tikus sekarang ini disebabkan aktivitas pabrik yang mengeluarkan bau busuk menyengat (amis) sehingga mengundang tikus untuk datang dan menyerang sawah warga disekitarnya, walaupun sawah tersebut tidak 
menggunakan air sungai sebagai pasokan airnya.

Sebelum adanya pabrik tepung ikan tersebut, hama tikus tidak sebanyak sekarang. Sebagian besar responden yang memiliki sawah mengatakan bahwa mereka gagal panen selama 1,5 tahun seperti yang dituturkan oleh S22.
Tanaman kacang tanah yang ditanam pada MT 3 juga tidak terlepas dari serangan tikus, kacang tanah yang siap panen terancam gagal panen (S23 dan S24). Nilai skor yang diperoleh pada Tabel 4 yaitu kemudian dibandingkan dengan skala persepsi untuk menentukan kategori pada Tabel 6.

Tabel 6.

Skala Persepsi Masyarakat Untuk Sub Variabel Bau/Aroma

\begin{tabular}{cc}
\hline Kategori & Nilai Skor \\
\hline Sangat Terganggu & $\mathbf{1 0 0 , 4} \mathbf{- 1 2 9}$ \\
Terganggu & $71,7-100,3$ \\
Tidak Terganggu & $43-71,6$ \\
\hline Sumber: Pengolahan Data $(2015)$.
\end{tabular}

Nilai skor yang diperoleh untuk persepsi masyarakat untuk sub variabel bau/aroma adalah sebesar 115, sehingga masuk dalam kategori Sangat Terganggu. Hal ini mengindikasikan bahwa bau sangat menyengat yang tercium oleh masyarakat di Desa Purworejo sudah sangat mengganggu kehidupan sehari-hari, bahkan beberapa warga yang istirahat malam bisa bangun karena bau busuk menyengat tersebut tercium pada malam hari.

\section{Persepsi Masyarakat Terhadap Air Limbah}

Persepsi masyarakat Desa Purworejo terhadap keberadaan industri tepung ikan ditinjau dari sub variabel air limbah disajikan Tabel 7. Sub variabel air limbah terdiri dari indikator air berbau dan kondisi saluran sungai.

Tabel 7.

Distribusi Frekuensi Responden Mengenai Persepsi Masyarakat

Sub Variabel Air Limbah

\begin{tabular}{lllcccc}
\hline No & Indikator & Kategori Jawaban & Nilai Skor & Frekuensi (orang) & Jumlah & Persentase (\%) \\
\hline 1 & Air & Sangat Terganggu & 3 & 2 & 6 & 4,65 \\
& berbau & Terganggu & 2 & 0 & 0 & 0 \\
& & Tidak Terganggu & 1 & 41 & 41 & 95,35 \\
\hline & & Jumlah & 3 & 43 & 47 & 100 \\
\hline \multirow{2}{*}{2} & Saluran & Sangat Terganggu & 3 & 4 & 12 & 9,30 \\
& sungai & Terganggu & 2 & 13 & 26 & 30,23 \\
& & Tidak Terganggu & 1 & 26 & 26 & 60,47 \\
\hline & Jumlah & & 43 & 64 & 100 \\
\hline & & & & 111 & Tidak \\
& & TOTAL & & & Terganggu \\
\hline
\end{tabular}

Sumber: Pengolahan Data (2015) 
Tabel 7 menunjukkan skor terbesar untuk sub variabel limbah sub air berbau 41 dengan persentase terbesar adalah jawaban dengan kategori Tidak Terganggu. Nilai skor ini mengindikasikan bahwa sebanyak 95,35\% dari jumlah responden menyatakan tidak terganggu dengan bau air limbah yang dihasilkan dari pabrik tepung ikan tersebut. Air limbah dari pabrik tepung ikan tersebut dibuang langsung ke Sungai Silugonggo setelah sebelumnya mengalami treatment di dalam pabrik. Dari 43 responden, sebanyak 2 responden $(4,65 \%)$ menyatakan bahwa bau air limbah tersebut sangat mengganggu (S1 dan S7).

Nilai terbesar untuk sub variabel air limbah sub saluran sungai diperoleh skor 26 dengan kategori terbesar adalah Tidak Terganggu. Hal ini berarti bahwa menurut jawaban para responden, sebagian besar masyarakat $(60,47 \%)$ merasa tidak terganggu dengan adanya air limbah yang ditimbulkan dari proses produksi industri tepung ikan yang dibuang ke Sungai Silugonggo.

Sebanyak 4 responden $(9,30 \%)$ mengemukakan bahwa air limbah yang dibuang ke Sungai Silugonggo Sangat Mengganggu dan sisanya sebesar 13 responden $(30,23 \%)$ menyatakan Terganggu atas pembuangan air limbah ke Sungai Silugonggo. Kondisi ini sangat merugikan masyarakat karena menurut mereka air limbah yang dibuang ke Sungai Silugonggo menyebabkan warga yang memiliki sawah di timur industri tepung ikan mengeluhkan gagal panen. Mereka berpendapat bahwa air buangan dari air limbah pabrik tepung ikan (terutama Industri Tepung Ikan A) menimbulkan bau amis yang dapat mengundang tikus ke lokasi tersebut.
Hal ini dikarenakan pipa pembuangan air limbah dari pabrik ke Sungai Silugonggo berada tepat di belakang rumah $\mathrm{S} 1$. Sehingga saat pembuangan air limbah itu berlangsung bisa dipastikan baunya akan sangat mengganggu. Alasan yang berbeda dikemukakan oleh S7. Menurut penuturan beliau, bau air limbah sangat menganggu saat S7 sedang mengairi sawah menggunakan air Sungai Silugonggo. Ketika air dipompa dari sungai ke sawah, baunya sangat menyengat dan berwarna hitam. Sedangkan sisanya yaitu sebanyak 41 responden $(95,35 \%)$ menyatakan tidak terganggu dari bau air limbah tersebut.

Sebagaimana diketahui bahwa air Sungai Silugonggo masih digunakan sebagai pasokan air bagi lahan pertanian yang berada di sekitarnya (lahan sawah di timur pabrik) terutama saat musim kemarau.

Menurut warga Dukuh Guyangan, selain bau menyengat yang berasal dari uap yang dihasilkan saat proses produksi, bau menyengat juga tercium saat pabrik membuang air limbah ke sungai, terutama warga yang berada di depan sungai tempat pembuangan air limbah. Hal ini disebabkan karena lokasi sungai tersebut berada tepat di belakang permukiman warga di Dukuh Guyangan. Beberapa warga Guyangan juga mengeluhkan adanya perbedaan rasa dari ikan yang ditangkap di sungai sejak pabrik tepung ikan tersebut membuang air limbah ke Sungai Silugonggo.

Untuk memperoleh gambaran yang lebih jelas mengenai persepsi masyarakat terhadap keberadaan pabrik tepung ikan dengan sub variabel air limbah dapat dilihat pada Tabel 8 . 
Tabel 8.

Skala Persepsi Masyarakat Untuk Sub Variabel Air Limbah

\begin{tabular}{cc}
\hline Kategori & Nilai Skor \\
\hline Sangat Terganggu & $200,7-258$ \\
Terganggu & $143,4-200,6$ \\
Tidak Terganggu & $86-143,3$ \\
\hline Sumber: Pengolahan Data $(2015)$.
\end{tabular}

Total skor pada Tabel 7 adalah 111, jika dibandingkan dengan skala persepsi pada Tabel 8 maka persepsi masyarakat terhadap keberadaan pabrik tepung ikan masuk dalam kategori Tidak Terganggu. Hal ini berarti menurut jawaban sebagian responden merasa tidak terganggu dengan air limbah baik dari baunya maupun air limbah yang dibuang ke Sungai Silugonggo. Kondisi ini dikarenakan air limbah yang dihasilkan pabrik akan langsung masuk ke sungai dengan volume dan debit air yang besar sehingga air limbah tersebut akan langsung tercampur dan terbawa aliran sungai. Persoalan air limbah tidak menjadi masalah berarti bagi kehidupan masyarakat di sekitarnya, karena hampir semua masyarakat Desa Purworejo tidak menggunakan air sungai untuk pemenuhan hidup sehari-hari. Mereka menggunakan air PDAM sehingga ketika ada pembuangan air limbah di Sungai Silugonggo itu, masyarakat merasa tidak terganggu. Masyarakat yang merasa sangat terganggu/terganggu merupakan masyarakat yang memiliki lahan sawah di sebelah timur pabrik yang masih menggunakan air Sungai Silugonggo sebagai pasokan air pada waktu tertentu. Serta sebagian masyarakat Dukuh Guyangan yang lokasinya berada di depan Sungai Silugonggo yang akan merasa sangat terganggu/terganggu waktu pembuangan air limbah ke sungai karena bau yang ditimbulkan sangat menyengat.

\section{KESIMPULAN DAN SARAN}

\section{Kesimpulan}

1. Persepsi masyarakat terhadap keberadaan industri tepung ikan untuk sub variabel tingkat kebauan termasuk dalam kategori Sangat Menyengat dengan nilai skor 123 .

2. Persepsi masyarakat terhadap keberadaan industri tepung ikan untuk sub variabel bau/aroma termasuk dalam kategori Sangat Terganggu dengan nilai skor 115 .

3. Persepsi masyarakat terhadap keberadaan industri tepung ikan untuk sub variabel air limbah termasuk dalam kategori Tidak Terganggu dengan nilai skor 111 .

\section{Saran}

1. Bagi dinas terkait BLH, Bappeda, Disperindag dan Dislautkan perlu mengkaji ulang penerapan RTRW yang menyatakan bahwa wilayah di lokasi penelitian merupakan wilayah yang kesesuaiannya untuk kawasan industri, dikarenakan wilayah tersebut merupakan wilayah genangan wan banjir.

2. Perlu dibentuk tim yang terdiri dari SKPD dan stakehoder terkait terutama yang berkaitan dengan isu lingkungan sehingga penyelesaian masalah lingkungan dapat teratasi secara lebih terintegrasi dan 
memberikan solusi baik bagi manusia maupun lingkungan.

3. Diperlukan adanya keterpaduan berbagai lintas sektor dalam mengelola, memantau dan mengevaluasi kegiatan industri, baik dari pihak pemerintah maupun swasta sehingga diharapkan dapat mengurangi dampak negatif yang muncul bagi lingkungan dan manusia yang dalam hal ini adalah bau dan air limbah yang ditimbulkan dari industri tepung ikan.

\section{DAFTAR PUSTAKA}

Anwar, A. A. 2012. Persepsi Masyarakat Terhadap

Keberadaan Peternakan Burung Puyuh di Kecamatan Pallangga Kabupaten Gowa. Skripsi. Fakultas Peternakan. Makassar: Universitas Hasanuddin.Widodo, W. 2009. Ketahanan Pakan Unggas di Tengah Krisis Pangan. Jurnal Protein Universitas Muhammadiyah Malang 12(1): $107-124$.

Data Monografi Desa Purworejo. 2015. Hasil Pendataan Keluarga (PK) Tahun 2015. Pemerintah Desa Purworejo, Kecamatan Pati, Kabupaten Pati.
Keputusan Menteri Negara Lingkungan Hidup Nomor 50 Tahun 1996 tentang Baku Tingkat Kebauan.

Laili, R. R. 2010. Proses Pembuatan Tepung Ikan di PT. Mayafood Industries Pekalongan Jawa Tengah. Laporan Magang. Fakultas Pertanian. Surakart: Universitas Sebelas Maret.

Nugraheni, M. 2010. Bahan Ajar Pengetahuan Bahan Pangan. BAB V Ikan. Mata Kuliah Pengetahuan Bahan Pangan. Yogyakarta: Universitas Negeri Yogyakarta.

Widyasari, R. A. H. E., C. M. Kusharto., B. Wiryawan., E. S. Wiyono., S. H. Suseno. 2013. Pemanfaatan Limbah Ikan Sidat Indonesia (Anguilla bicolor) Sebagai Tepung Pada Industri Pengolahan Ikan di Pelabuhan Ratu, Kabupaten Sukabumi. Jurnal Gizi dan Pangan 8(3): 215-220.

\section{BIODATA PENULIS}

Arieyanti Dwi Astuti, lahir 24 Agustus 1984 di kota Pati Jawa Tengah. Sarjana (S1) dari Universitas Diponegoro (UNDIP) Semarang Jurusan Teknik Lingkungan Tahun 2007. Saat ini bekerja sebagai peneliti di Kantor Penelitian dan Pengembangan Kabupaten Pati. 